DOI: 10.14807/ijmp.v11i9.1418

\title{
INFORMATION AND ANALYTICAL PROVIDION OF BUDGET SUPPORT OF INSTITUTIONAL SECTORS OF THE ECONOMY (ON THE EXAMPLE OF THE AGRICULTURAL SECTOR OF UKRAINE)
}

\author{
Oksana Radchenko \\ National Scientific Center "Institute of Agrarian Economics", Ukraine \\ E-mail: oxanarad@ukr.net
}

Maryana Matveyeva
Stepan Gzhytskyi National University of Veterinary Medicine and
Biotechnologies, Ukraine
E-mail: mmplviv71@gmail.com

Hanna Holovanova

Petro Vasylenko Kharkiv National Technical University of Agriculture, Ukraine E-mail: golovanovaae.2003@gmail.com

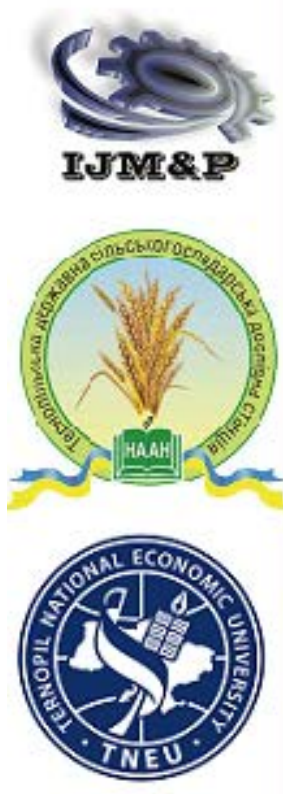

Kateryna Makhyboroda
National University of Life and Environmental Sciences of Ukraine, Ukraine
E-mail: vdovenko.katya@ukr.net

Yuliia Haibura State Agrarian and Engineering University in Podilya, Ukraine E-mail: hayburay@gmail.com

Submission: 8/13/2020

Revision: 8/26/2020

Accept: 9/10/2020

\section{ABSTRACT}

The aim of the article is to study the information support of the institutional field and state regulation of agricultural development of Ukraine through the analysis of current strategies and tools and programs of state support. The relevance of the study is due to the significant increase in the role of state support for key sectors of the economy in a systemic crisis caused by the coronavirus pandemic COVID-19 and restrictive quarantine measures. Limitation of budget funds implies an urgent need for their most rational use, identifying trends and areas of which this study is devoted. The research methodology is based on comparative analysis, economic and mathematical modeling, methods of assessing the effectiveness of budget programs, the use of analytical surveys, statistics on selfassessment of agribusiness and data from independent news agencies on the effectiveness of government regulation. 
DOI: 10.14807/ijmp.v11i9.1418

The information base is the regulatory framework for state support of the agricultural sector, analytical studies on budget support for the agricultural sector and budget expenditures for agricultural development were based on official data from the State Statistics Service of Ukraine and the Ministry of Economy, Trade and Agriculture of Ukraine. The study analyses some components of the Strategy for the development of the agricultural sector of Ukraine, the Concept of development of farms and agricultural cooperation for 2018-2020, the project and the place of state support in its regulation. The dynamics of state support for 2016-2019 is shown, the main factors of influence are characterized and the dynamics of state support of the agricultural sector of Ukraine evaluated according to the OECD (Organization of economic cooperation and development) methodology is given. An analysis of the expenditures of the State Budget of Ukraine in 2020 on agricultural and rural development is carried out. The given research can be used at formation of current programs of budgetary support of branch, development of concepts of sustainable development of separate forms of managing - farms and peasant farms, adjustment of strategic plans, formation of their key indicators for monitoring and for increase methodological bases and principles of state regulation and other institutional factors of agricultural finance.

Keywords: Information support; Budgetary financing; Agricultural sector; Institutions; Ukraine; State support programs; Indicators of OECD agricultural support; Systemic crisis

\section{INTRODUCTION}

State agricultural support provides a system of measures aimed at reproducing the material and technical base, achieving the required level of profitability, support for social and environmental programs.

Since the market orientation of the economy, it has undergone significant changes, but the basic principle of budget financing according to the list of many different measures has been preserved. In the conditions of the chosen vector of European integration, especially after accession to the WTO, the state support policy strives for the strategies adopted by the EU CAP.

In addition, state support, following the abolition of special corporate tax regimes in Ukraine, has faced a predominance of direct support methods with low funding and skilful manipulation of the agrarian lobby of large enterprises in the distribution of budget funds in their favour. Based on these trends, there is a need to make a scientific generalization of the achievements and challenges of state policy to support agriculture in Ukraine. 
DOI: 10.14807/ijmp.v11i9.1418

An important component of the effectiveness of this area of public administration is its information support. According to the Law on Basic Principles of Information Society Development in Ukraine (2007) certain legal bases have been formed: a number of normative legal acts have been adopted, which, in particular, regulate public relations on creation of electronic information resources, protection of intellectual property rights, introduction of electronic document management, information protection.

It is noted that the efficiency of the use of financial, material, human resources aimed at informatization, introduction of information and communication technologies (hereinafter ICT) in the social and economic sphere, in particular in agriculture, is low; there is a lag in the introduction of e-business technologies, electronic exchanges and auctions, e-depositories, the use of non-cash payments for goods and services, etc. The main directions of information support development in the framework of our study provide for the introduction of a system of indicators of information society development in Ukraine with appropriate changes in the system of state statistical surveys in accordance with international standards and methodology and their annual publication.

We see that the study of state support should be carried out through the theories of institutions, which are one of the most methodologically productive areas of economic theory in the study of the content, ways and mechanism of implementation of systemic transformations. In addition, such analysis of economic systems determines the entry into the plane of active interdisciplinary interaction with other social sciences and involvement in the study of a wider range of variables that are not purely economic in nature, but determine the implementation of economic processes and economic development - historical, social, legal and political, etc. As we considered earlier (SEMENYSHENA; RADCHENKO, 2020; RADCHENKO; TULUSH, 2020; SEMENYSHENA; RADCHENKO, 2011; RADCHENKO, 2017; RADCHENKO; LAZUTINA, 2017; RADCHENKO, 2019; RADCHENKO; MELNYCHUK, 2019), today state regulation is carried out by through a holistic system of tools: pricing policy, budget support through the mechanisms of budget financing and preferential taxation, credit support, insurance promotion, etc., which together constitute the institutional aspects.

In the context of the systemic crisis caused by the pandemic of coronavirus COVID-19 and restrictive quarantine measures, the role of state support for the most important sectors of the economy is growing significantly. Limited budget funds imply an urgent need for their most rational use, identifying trends and directions of which this study is devoted. 
DOI: 10.14807/ijmp.v11i9.1418

\section{LITERATURE REVIEW}

Scientists, experts and practitioners of Ukraine study the state support of agriculture, in particular: Borodina and Kyryziuk (2008), Prokopa and Borodina (2016), Moldavan (2016), Demianenko and Sabluk (2011), Dibrova and Halushko (2006), Oliynyk and Kalashnikov (2014), Laiko (1998), Lupenko (2012) and others.

Information support of public policy management as a communication aspect of the interaction of society, business and the state is developed within the system, where integration is possible through information and cognitive, with integration through the mental abilities of people modules.

Lyiniov (2015) notes that public administration in general and its information (information and analytical) support is influenced in modern conditions by the following factors: geopolitical processes, primarily globalization as an integration process; informatization; democratization and development of civil society; progress in the field of management and technologies of information activity, etc. That is why information services must have appropriate communication capabilities, organizational and staffing structure, as well as a system of protection against manipulative influences and other threats to information (information and psychological) security.

The above-mentioned researchers have generally identified the main advantages and disadvantages of the current mechanism, develop appropriate strategies and concepts, but the problem is so multifaceted that it requires constant scientific monitoring to organize a sound practice of state support management in Ukraine.

Zhalilo (2009) points to the theoretical and practical aspects of the formation and implementation of economic strategy of the state in terms of ensuring its maximum effectiveness, examining the relationship of economic strategy of the state with the objective macroeconomic laws and motivation of major economic actors and indicates a significant increase institutional factors of efficiency of economic strategies of all levels in the conditions of fast economic growth.

These researchers determined that the main problems of state support for agriculture in Ukraine are: lack of trust in the state by farmers; insufficient level of impact of budget support measures on the development of domestic agriculture. This is due to the fact that budget support programs in Ukraine suffer from constant underfunding; as well as the rules for allocating budget funds for the respective program grants are usually approved on an annual basis and 
DOI: $10.14807 /$ ijmp.v11i9.1418

often change from year to year (i.e. agricultural producers often do not receive support when they urgently need it).

The scientist Ostapenko (2015) also found that the functioning of the agro-industrial complex in Ukraine is based on a subsidized approach, which is focused on self-sufficiency and increase production. The existing system of tax benefits combined with non-transparent budget support is unable to stimulate the transition of most agricultural enterprises to highly efficient management methods based on modern equipment and technologies that provide a high level of productivity of all resources on a sustainable basis. At the same time, a significant imbalance between tax revenues from agro-industrial enterprises and budget expenditures (both direct, in the form of subsidies and indirect, in the form of underpayment of tax revenues) in favour of the latter, lead to tax burden transfer to other sectors of the national economy.

Directly for the agricultural sector, the communication function has certain features described by Semenyshena (2011). Researchers have recognized that the use of information space and information technology by public authorities becomes a direct factor in economic growth, social and political stability and the development of democratic principles in government.

Soloviov et al. (2015) note that important aspects of information and analytical support of sustainable development policy are the advance identification of threats and risks to sustainable development and forecast development. This requires a transition to prognostic forms of activity, not just a statement of facts (acquaintance with primary information), but a systematic approach to solving the problem in general based on a combination of intellectual abilities of staff of information and analytical units (management) with the functionality of modern information and telecommunications systems.

Foreign researchers also analyze government support, comparing the budget for agriculture by the capabilities of countries and in the conditions of the European Union, in particular: Zawisza, Prus and Beben (2019), Milojevi and Určić (2017), Heinemann and Weiss (2018), Călin, Izvoranu and Todirica (2020), Matthews (2016), Scown, Brady and Nicholas (2020) who and others.

The aim of this paper has been to determine Zawisza, Prus and Beben (2019) the prospects for the development of agricultural family farms. With that in mind, an important aspect has been to diagnose the opinions of the farmers on the key sources of income, benefiting from the CAP support, the recent investment projects completed, opinions on changes in the 
DOI: 10.14807/ijmp.v11i9.1418

operation of agriculture after the integration with the $\mathrm{EU}$, its impact on the development potential of the farms under study as well as plans for the farms. The survey research has demonstrated that a great majority of the respondents were living mostly from agricultural production, only some used other support than direct payments.

Milojevi and Určić (2017) investigated that financing for agricultural development is one of the basic tasks of a condition of economic growth of any country. Focusing on the financial institution budgets may be present level of need and the possibility of meeting the basic social needs, with the aim of establishing and functioning of agriculture as primary branch of the economy in the Republic of Serbia. Using statistical methods present the causal relationships between the elements of financing agriculture and their main financial strongholds, the economic power of the state, with reference to the agricultural sector of the Republic of Serbia.

The European Commission's proposals for the post-2020 Common Agricultural Policy (CAP) are under discussion, and these cautious reform ideas have set the parameters for upcoming negotiations. CAP will continue to have a two-pillar structure of direct payments and rural development, with a seven-year budget of $€ 365$ billion. As before, almost threequarters of the budget - €265 billion - is reserved for direct payments to farmers. However, 'European added value' must be urgently applied to CAP, say Heinemann and Weiss (2018), who have developed a series of recommendations to justify direct payments in their latest report for EconPol.

EU producers are highly dependent on public support Matthews (2016). The EU average share of direct payments in agricultural factor income in 2010-2013 stood at 28\%. However, this masked considerable differences between member states, ranging from $15 \%$ or less in Cyprus, Lithuania, Malta, the Netherlands and Romania to more than $40 \%$ in Ireland, Luxembourg, Slovakia and Sweden. These differences reflect the specialization of member states in different sectors as well as differences in the historical basis of payments. Taking all subsidies into account, total public support from the EU budget in agricultural income reached $40 \%$ of agricultural income on average in the EU.

Scown, Brady and Nicholas (2020), we analyzed the distribution of $€ 59.4$ billion of 2015 CAP payments and show that current CAP spending exacerbates income inequality within agriculture, while little funding supports climate-friendly and biodiverse farming regions. More than $€ 24$ billion of 2015 CAP direct payments went to regions where average farm incomes are 
DOI: 10.14807/ijmp.v11i9.1418

already above the EU median income. A further $€ 2.5$ billion in rural development payments went to primarily urban areas.

Călin, Izvoranu and Todirica (2020) studying the effects of globalization would be meaningless if we did not focus on studying it on the most important sector, namely the agricultural sector. In an international scenario marked by uncertainty and anticipation after, the European Union pays particular attention to the application of a territory of effective policies in response to increased competition in markets, and represents an interesting tool for government intervention in development rural area in a defined area of quality products. In this direction in the last years, the European Union has authorized state aid for implementation supply chain contracts, as well as the sector for the purpose promoting and modernizing agriculture, as well as technological development enterprises.

The development of farms in terms of state support is thus the basis of agricultural policy. It is necessary to summarize the best European experience for Ukraine.

The purpose of the study is to analyse the achievements and identify the main threats to the development of state support for agriculture in Ukraine through an institutional analysis of its structure and dynamics.

\section{METHODOLOGY}

Methodological tools of the study include: identification of the problem situation that necessitates the study. It is obvious that in the conditions of the crisis the distribution of budgetary resources on the main branches of the economy will change, and it is necessary to predict them; the definition of the object and subject of research is within the framework of state regulation of financial resources for agricultural entrepreneurship, so the object is the relationship of resource allocation, and the subject - budget funding and its structure. The study states a structural (logical) analysis of the object of budget funding; working hypotheses about priority directions of distribution of budgetary funds of the agrarian budget of Ukraine and connection of this process with international tendencies are put forward.

The theoretical level of research is related to the analysis of facts, with the penetration into the essence of the studied phenomena, their cognition according to the following criteria: the sequence of use of the method; subordination to the achievement of the practical goal - the improvement of state budget support programs. The main general scientific methods of cognition within the institutional theory of public administration of economic sectors are used.

\section{RESULTS}


DOI: 10.14807/ijmp.v11i9.1418

\subsection{State support for the agricultural sector in Ukraine}

State support for the agricultural sector is provided in areas that guarantee food security and sustainable rural development. Thus, the main objectives of the 10-year European plan for Ukraine (2017) - building a favorable investment environment and supporting economic growth, which is planned to attract 50 billion euros by 2027. Directly, a project "Accelerating Investment in Agriculture of Ukraine” (2019) is provided for the agricultural sector.

Among the pre-defined agricultural components of the project: harmonization of Ukrainian legislation with EU requirements, improvement of the state support system for agriculture, stimulation of diversification of agricultural production, rural development, strengthening food security capacity, solving logistics issues, improving land use, improving water management resources, improving access to agricultural resources, improving access to financial resources and risk management tools.

The Ministry of Agrarian Policy has developed the Strategy “The only comprehensive strategy and action plan for the development of agriculture and rural areas in Ukraine for 20152020” (2014), which identifies three key priorities for reforming the sector: approximation of legislation to EU standards and deregulation; increasing the competitiveness of agriculture; as well as rural development and environmental protection. Among the many goals of state support and taxation in the field of agriculture include: revision and improvement of the system of state support for agricultural producers and reduction of administrative pressure by simplifying the taxation system of the industry.

NSC “Institute of Agrarian Economics” outlines the strategic directions of agricultural development (2012), etc. Accordingly, more or less public funds are allocated for these purposes or institutional regulation measures are developed, as in accordance with the requirements of international organizations (WTO, IMF), member states have clear requirements for governance in the field of agriculture.

During the period 2016-2018, the actual state support of the industry amounted to UAH 10.429 billion (Table 1). State support programs for agricultural producers have been relatively sustainable.

Table 1: State of financing of state support for the development of the agricultural sector in 2016-2019, UAH mln

\begin{tabular}{|l|c|c|c|c|c|c|}
\hline program /direction & $\begin{array}{c}\text { In fact } \\
\mathbf{2 0 1 6}\end{array}$ & $\begin{array}{c}\text { In fact } \\
\mathbf{2 0 1 7}\end{array}$ & $\begin{array}{c}\text { In fact } \\
\mathbf{2 0 1 8}\end{array}$ & $\begin{array}{c}\text { Plan for } \\
\mathbf{2 0 1 9}\end{array}$ & $\begin{array}{c}\text { Made on } \\
\mathbf{1 1 . 2 0 1 9}\end{array}$ & $\begin{array}{c}\mathbf{2 0 1 9} \\
\mathbf{\%} \text { plan }\end{array}$ \\
\hline 2801030 cheaper loans & 280 & 295 & 266 & 127 & 104 & 81.89 \\
\hline
\end{tabular}


INDEPENDENT JOURNAL OF MANAGEMENT \& PRODUCTION (IJM\&P)

http://www.ijmp.jor.br

v. 11, n. 9, Special Edition (Baltic States), November 2020

ISSN: 2236-269X

DOI: 10.14807/ijmp.v11i9.1418

\begin{tabular}{|l|c|c|c|c|c|c|}
\hline $\begin{array}{l}2801230 \text { support for the } \\
\text { development of farmers }\end{array}$ & - & - & 203 & 800 & 230 & 40.21 \\
\hline $\begin{array}{l}2801350 \text { support for the } \\
\text { development of } \\
\text { horticulture }\end{array}$ & - & 299 & 394 & 400 & 120 & 39.74 \\
\hline 2801460 loans to farmers & - & - & - & 200 & 140 & 77.78 \\
\hline $\begin{array}{l}2801540 \text { support for the } \\
\text { livestock industry }\end{array}$ & 30 & 166 & 2390 & 3500 & 1600 & 56.62 \\
\hline $\begin{array}{l}2801580 \text { support for } \\
\text { commodity producers, etc. }\end{array}$ & - & 4134 & 912 & 882 & 640 & 90.52 \\
\hline other programs & 596 & 471 & 303 & 415 & - & - \\
\hline Total by region: & 5365 & 4468 & 6324 & 2834 & 60.11 \\
\hline
\end{tabular}

Source: author's calculations based on: The State Fiscal Service of Ukraine. Retrieved from: http://sfs.gov.ua/; The State Treasury of Ukraine. Retrieved from: http://www.treasury.gov.ua/main/uk/index

Currently, there are programs: support for activities in the agro-industrial complex by reducing the cost of loans; support for farm development; support for the development of hop growing, establishment of young gardens, vineyards and berries; providing loans to farms; support for livestock, storage and processing of agricultural products, aquaculture; financial support for agricultural producers. Within these programs there are targeted areas, for example, financial support for farmers includes measures: partial compensation for seed costs, compensation for costs associated with agricultural advisory services, support for agricultural service cooperatives, partial compensation for purchased agricultural machinery and equipment of domestic production, budget per hectare, cheaper loans and repayment of accounts payable.

In 2019, UAH 5.9 billion is provided for state support programs for the agro-industrial complex, which is UAH 1.7 billion more than in 2018. As of the beginning of 2020, funding for state support programs has been fulfilled by $48 \%$ of the annual plan and $60 \%$ of the plan for the period.

The state of funding, as in 2018, is unsatisfactory. Despite the fact that there are clearly insufficient funds planned, even within the limits of at least $1 \%$ of the gross output of the industry initiated by the former Ministry of Agrarian Policy, the allocated funding is not used properly. According to the above data, the plan for 2019 was implemented only under the program of providing loans to farms.

According to the "Information and analytical portal of the AIC of Ukraine" (2019), farmers received UAH 104 million to compensate for interest on loans, the largest amounts of which were received by farmers in Vinnitsa, Cherkasy and Kyiv regions. Preferential loans worth over UAH 4 billion were attracted. 
DOI: 10.14807/ijmp.v11i9.1418

The most important program, state support for livestock, storage and processing of agricultural products, aquaculture (fish) UAH 3.5 billion is provided by the budget for 2019, implemented by 46\% (in 2018, UAH 3.5 billion was spent). In the field of animal husbandry, according to the "Information and analytical portal of the AIC of Ukraine" (2019), the receipt of documents for obtaining a subsidy for the maintenance of cows, which received more than 1.000 applications, the total amount of funding for which is UAH 700.0 million. The grant is provided twice a year and has already been used by 885 business entities to keep 307.000 cows.

During this period, UAH 640 million was allocated within the program of partial compensation from the state budget for the cost of purchased agricultural machinery and equipment of domestic production. If earlier the program included less than 800 items of machinery and equipment, now - more than 12.5 thousand. By September, the program was used by almost 3 thousand farmers who purchased 5,104 units of machinery and equipment worth a total of 1.6 billion UAH.

In addition, according to the Financial support for the development of agricultural enterprises at the expense of local budgets for the first quarter of 2019 (2019) for 2019 in accordance with the adopted regional programs to support the development of agro-industrial enterprises it is planned to allocate UAH 262.5 million, which is UAH 54.6 million more than in 2018 (UAH 207.9 million). In the first quarter of this year, UAH 34.3 million was actually financed, only $13.1 \%$ of demand.

Thus, the presented state programs to support agriculture at the end of 2019 are characterized by significant underfunding. Although the budget manager guarantees that the situation with state support will be resolved by the end of the year, the budget will receive the necessary revenues and the programs announced by the government will be funded, state support not only effective consumer demand for products and prevention of unprofitable producers. According to the data, the livestock industry is in the lead in the structure of expenditures - almost $60 \%$, followed by financial support for producers (a program to reduce the cost of purchasing domestic equipment) - 15\% and support for farmers - $13.5 \%$.

In turn, according to the Accounting Chamber "On the results of the audit of the effectiveness of the exercise of powers by public authorities in terms of completeness and timeliness of payment of taxes by economic entities in agriculture”: report (2018) state of settlements with the state budget sub of agricultural facilities for the relevant period (from 2016 to the first half of 2018) is as follows: UAH 39.713 billion was paid to the state budget (3.7 
DOI: 10.14807/ijmp.v11i9.1418

times more than budget agricultural expenditures), including UAH 37.742 billion VAT, UAH 1.741 billion of income tax and UAH 0.230 billion of export duty, the share of which in the total state budget revenues increased from $0.96 \%$ to $8.4 \%$ for the analyses period.

Thus, the presented state programs to support agriculture at the end of 2019 are characterized by significant underfunding. Although the budget manager guarantees that the situation with state support will be resolved by the end of the year, the budget will receive the necessary revenues and the programs announced by the government will be funded, state support not only effective consumer demand for products and prevention of unprofitable producers.

\subsection{Institutional risks of state support and regulation of the agricultural sector in Ukraine}

The agricultural sector of Ukraine operates in conditions of uncertainty related to the government's actions regarding state support, as well as tax legislation, customs regulation of export-import operations. In addition, in the context of European integration, there are institutional risks due to restrictions in financial and credit, environmental protection, land use, etc., related to the requirements of Ukraine's foreign partners. Exporting and importing countries are quite closely linked, and therefore the income of the sector is affected by events in other countries. It is the institutional risks that caused the negative importance of state support in Ukraine, determined according to the OECD methodology of Agricultural Policy Monitoring and Evaluation 2018 (2019), (Table 2).

Table 2: Assessment of state support for agriculture in Ukraine according to the OECD methodology, 2015-2017, UAH mln

\begin{tabular}{|l|c|c|c|c|}
\hline \multicolumn{1}{|c|}{ Indicators } & $\mathbf{2 0 1 5 - 2 0 1 7}$ & $\mathbf{2 0 1 5}$ & $\mathbf{2 0 1 6}$ & $\mathbf{2 0 1 7}$ \\
\hline Production cost & 26848 & 25701 & 26354 & 28488 \\
\hline Cost of products consumed & 15876 & 16042 & 16171 & 15415 \\
\hline Aggregate Support Assessment (PSE) & -2112 & -2016 & -2278 & -2043 \\
\hline (\% PSE) & -7.7 & -7.5 & -8.5 & -7.1 \\
\hline Product support & -2720 & -3129 & -2799 & -2234 \\
\hline Market price support & -2720 & -3129 & -2799 & -2234 \\
\hline Resource support & 547 & 930 & 521 & 191 \\
\hline Nominal protection factor. \% NPC & 0.90 & 0.88 & 0.90 & 0.92 \\
\hline Nominal support ratio. \% NAC & 0.93 & 0.93 & 0.92 & 0.93 \\
\hline General Services Support Assessment (GSSE) & 121 & 115 & 110 & 139 \\
\hline Customer Support Assessment (CSE) & 1701 & 1813 & 1903 & 1387 \\
\hline Aggregate Support to Agriculture (TSE) & -1991 & -1901 & -2168 & -1904 \\
\hline (TSE\% of GDP) & -2.0 & -2.1 & -2.3 & -1.8 \\
\hline
\end{tabular}

Source: author's calculations based on: The State Statistics Service of Ukraine. Retrieved from: http://ukrstat.gov.ua; European plan for Ukraine. Available at: https:/g8fip1kplyr33r3krz5b97d1wpengine.netdna-ssl.com/wp-content/uploads/2017/11/Presentation-EuropeanPlanUkraineupdate.pdf 
DOI: 10.14807/ijmp.v11i9.1418

Aggregate assessment of percentage support (\% PSE) characterizes the cost of transfers to producers to the total effective cost of production. According to an OECD report, PSE has remained negative in Ukraine over the past five years due to the difference between domestic and world prices for exported products, which is a kind of implicit taxation of the sector.

The nominal protection coefficient (NPC), defined as the ratio of domestic to world prices below 1, means that Ukraine's agriculture is not supported, moreover, it serves as a source of indirect taxation in favor of consumers. Nominal aid coefficient (NAC), as the ratio of funds actually received by producers to world prices, is an index of national prices to world prices and is almost identical to the protection rate.

In general, the state of the domestic agro-industrial complex is increasingly contrasting with the changes inherent in the developed world, where agriculture is confidently transforming from a traditionally subsidized industry to a self-sufficient powerful industry, which is one of the driving forces of social and economic growth, the primary area of application of scientific and technological progress. This confirms, according to SIRENKO'S research (2010), that the measures of state regulation implemented in the agro-industrial sphere of Ukraine remain insufficiently effective and need to be reviewed in the context of the most important areas of economic modernization.

OECD advice includes actively using the preferences provided by free trade agreements with the EU and Canada, investing in transport infrastructure and logistics, introducing a land market and ensuring adequate access to agricultural credit.

The move towards European integration takes into account the fact that the EU CAP is moving from purely agricultural support to support for sustainable rural development. For Ukraine, until recently, rural development was seen as a component of non-productive allocations to agriculture, as sectoral and territorial factors were integrated in Ukraine's agricultural economy (RADCHENKO, 2017; RADCHENKO; LAZUTINA, 2017).

Therefore, taking into account the experience of EU countries, where agricultural policy combines elements of regulatory market, price, foreign trade and structural policy, most domestic scholars note that state support for agricultural development and sustainable development of rural areas of Ukraine are close but not identical tasks and therefore position as a strategic direction equal priority of state support for the development of agrarian business and rural areas. 
DOI: 10.14807/ijmp.v11i9.1418

In particular, the new political and economic realities of our time have significantly influenced the management and regulation of the agricultural sector. The key issue being discussed at various levels is the opening of the land market (The World Bank, 2020). From its solution and legislative design depends on the further development of agricultural production, the efficiency of agriculture and the national economy, the state of foreign trade balance, rural development, welfare, etc.

According to the Ministry of Economic Development, Trade and Agriculture (MDET) of Ukraine, the Ministry for Development of Economy, Trade and Agriculture of Ukraine (2020) has declared goals that: Ukrainians do not lose the ban on disposing of their property; receive safe goods and services; have a legal job; receive more income from state property management; do not overpay for services and goods; get better export conditions; protected from the abuse of monopolists.

The effectiveness of these plans depends on their financial base, according to which the relevant ministry plans that Ukrainians live in a state that is supposed to manage public finances; taxpayers have a lower tax burden and spend much less time on their administration; bona fide exporters and importers and citizens of Ukraine have transparent, simple and predictable rules of customs control and customs clearance, while their economic interests and interests in terms of equality of competitive conditions are protected; businesses and citizens have access to much cheaper financial resources; taxpayers' debt service costs are declining.

In anticipation of the opening of the land market, in the draft State Budget-20 to support producers in the program code 1201040 was laid UAH 4.4 billion, which was supposed to be used to compensate for the rates for the purchase of agricultural land. The interest rate on loans for the purchase of agricultural land in Ukraine after the opening of the land market will be within $3-5 \%$ per annum, and the rest of the interest on loans will be reimbursed by the state.

The Agrarian Committee of the Verkhovna Rada (2020) proposed to maintain the amount of support for the agro-industrial complex at 1\% of GDP for 2020, which is UAH 8.4 billion, of which UAH 4.4 billion will be allocated to the program to reduce the cost of loans related to purchase of land, and the remaining UAH 4 billion to be allocated to sectoral programs.

Accordingly, before the adoption of the Law on the State Budget-20 Law on the State Budget of Ukraine for 2020 (2019), the Parliament previously on November 13, 2019 supported the Law on Land Market, which is expected to open on October 1, 2020, which 


\section{INDEPENDENT JOURNAL OF MANAGEMENT \& PRODUCTION (IJM\&P)}

http://www.ijmp.jor.br

v. 11, n. 9, Special Edition (Baltic States), November 2020

ISSN: 2236-269X

DOI: 10.14807/ijmp.v11i9.1418

provides for a rule On January 1, 2024, the purchase of land by legal entities whose beneficial owners are foreigners and stateless persons is not allowed. However, in the adopted State Budget 2020 this program is absent, and the amount close to it is included in the program of financial support of commodity producers.

Funds for state support to agricultural producers are aggregated under one program (code 1201150) in the amount of UAH 4 billion, but in the accompanying materials there are no explanations on the use of such funds (in particular, on the areas of such support), excluding expenditures UAH 4.4 billion to reduce the cost of loans to agricultural producers for the purchase of agricultural land.

Directions, volumes and managers of budget expenditures for agricultural development in the State Budget-20 are presented. Approved programs and funding are shown in Table 3.

Table 3: Distribution of planned expenditures of the State Budget of Ukraine for 2020 in terms of financing of agricultural and rural development, thousand UAH

\begin{tabular}{|l|l|c|c|c|}
\hline & \multicolumn{1}{|c|}{ Costs by destination } & General Fund & Special Fund & Total \\
\hline 1 & Total for agriculture & 433130.0 & 149100.0 & 4481029.5 \\
\hline 2 & Together agricultural sector services & 105162.6 & 770682231.80 & 18223828231.80 \\
\hline 3 & Together. other service costs & 2781858.2 & 2006419.8 & 4788278.0 \\
\hline 4 & $\begin{array}{l}\text { Total agricultural development costs }(1+2 \\
+3)\end{array}$ & 7218950.8 & 2232589.0 & 9451539.3 \\
\hline 5 & Together lending & 71773.00 & - & 71773.0 \\
\hline 6 & $\begin{array}{l}\text { General financing of agricultural } \\
\text { development }(4+5)\end{array}$ & 7290723.80 & 2232589 & 9523312.3 \\
\hline
\end{tabular}

Source: Law on the State Budget of Ukraine for 2020 Electronic resource. URL: http://w1.c1.rada.gov.ua/pls/zweb2/webproc4_1?pf3511=66853

Expenditures on agriculture for 2020 (group 1, table 3) are grouped by programs: financial support of measures in the agro-industrial complex, the costs of the Agrarian Fund are associated with a set of measures for storage, transportation, processing and export of state price regulation of state intervention fund, financial support of agricultural producers, organization and regulation of institutions in the agro-industrial complex and ensuring the activities of the Agrarian Fund, the formation of the authorized capital of the Partial Credit Guarantee Fund. In terms of volume, these expenditures amount to UAH 4.332 billion for the general fund (96.7\%), UAH 0.149 billion for the special fund, and a total of UAH 4.481 billion (47\% of total agricultural development expenditures).

Expenditures on agricultural services (group 2, table 3) include programs: scientific and scientific-technical activities in the field of agro-industrial complex development, standardization and certification of agricultural products, advanced training of agro-industrial complex specialists, research, applied scientific and scientific-technical developments, 
DOI: 10.14807/ijmp.v11i9.1418

implementation works under the state target programs and the state order, preparation of scientific shots and financial support of development of a scientific infrastructure in the field of economic development, liquidation and ecological rehabilitation of the enterprise "Solotvynskyi salt mine". In terms of volume, they amount to UAH 105.16 million for the general fund, UAH 77.07 million for the special fund, and a total of UAH 182.231 million. These programs were financed in previous budgets, and their share in the structure of agricultural development expenditures is $2 \%$.

Expenditures on agricultural services in other ministries (group 3, Table 3) are financed by the following programs: land reform, land inventory and updating the cartographic basis of the State Land Cadaster, anti-epizootic measures and participation in the International Epizootic Bureau, organization and regulation of institutions in the system State Service of Ukraine for Food Safety and Consumer Protection, measures to build border inspection posts and improve access of agricultural SMEs to export markets, accelerate investment in agriculture of Ukraine, implementation of measures to support research farms. Funding for them is calculated 4.738 billion UAH, in the structure of $56.8 \%$ is the general fund. Their share in agricultural development expenditures is $50 \%$.

When planning the State Budget-20 for the implementation of measures for land reform, the funds of the general fund in the amount of UAH 76.1 million are taken into account, which, in particular, provides for the maintenance and operation, including administration, of the State Land Cadaster, its technical and technological support, as well as the conversion of materials of the State Fund of land management documentation into electronic (digital) form, which will ensure the smooth operation of the State Land Cadaster. Expenditures from the general fund of the state budget in the amount of UAH 430.6 million are envisaged for conducting the land inventory and updating the cartographic basis of the State Land Cadaster, which will provide an opportunity to assess the land fund of Ukraine.

The Accelerated Investment in Agriculture Program of Ukraine includes funds approved by the World Bank's Board of Executive Directors for a \$ 200 million loan for the implementation of the Program based on the results of accelerating private investment in agriculture. The program aims to empower small and medium-sized enterprises in the agricultural sector.

The program aims to strengthen the competitiveness, diversification and development of agriculture by increasing the efficiency and targeting of industry support policies, improving 
DOI: 10.14807/ijmp.v11i9.1418

transparency and efficiency of state-owned agricultural land, as well as expanding access of agricultural SMEs to export markets. In the structure of expenditures by group of expenditures on agricultural services in other ministries, they account for $13 \%$.

The World Bank has estimated at \$ 500 million the amount needed to partially guarantee farmers' land costs. The opening of the land market can bring Ukraine's economy up to $\$ 1.5$ billion annually, plus $1.5 \%$ to GDP growth. A moratorium on land sales is a major obstacle to attracting investment to Ukraine, according to The World Bank (2020).

In the area of lending to agriculture, there are programs for lending to farms and financial support for measures in the agro-industrial complex on the terms of financial leasing in the amount of UAH 72 million. In the structure of financing agricultural development, they account for $0.8 \%$.

As Table 3 shows, funding for individual agricultural support programs will be provided from a special fund. In particular, the special fund will include: formation of the state reserve seed fund, organization and regulation of institutions in the system of the State Service of Ukraine for Food Safety and Consumer Protection, project "Acceleration of private investment in agriculture of Ukraine", financial support of measures in the agro-industrial complex on the terms of financial leasing, etc.

In Article 13 of the Law on the State Budget of Ukraine 2020 establishes that the sources of formation of the special fund of the State Budget of Ukraine for 2020 in terms of lending are revenues specified in part three of Article 30 of the Budget Code of Ukraine, as well as the following revenues: 1) repayment of budget loans products under the state order (contract) of 1994-1997; 2) return of funds provided for financial support of measures in the agro-industrial complex on the terms of financial leasing, as well as the purchase of breeding heifers and cows, domestic machinery and equipment for the agro-industrial complex, followed by their sale to agricultural enterprises on financial leasing.

As for the budget funding of the industry, due to the pandemic, it has undergone some changes, although it has not affected the planned volumes. The systemic crisis, which affected all countries, had a significant impact on financial flows in the agricultural sector. In particular, FAO economists (To feed everyone and not starve to death, 2020) note that if we summarize a small intermediate result, the advantage will be in those countries that produce everything necessary to fully provide their populations with food and are not very dependent on imports or exports. 
DOI: 10.14807/ijmp.v11i9.1418

As researched by Radchenko and Tulush (2020), the European Union has developed "green stripes" to ensure the flow of products. The government's crisis aid package for farmers includes private storage assistance (PSA) measures in the dairy and meat sectors, authorization of market self-organization by operators in the affected sectors, and flexibility for fruit and vegetables, wine and some other market support programs according to data "Supporting the agriculture and food sectors amid Coronavirus” (Coronavirus, 2020). Measures and financing of direct programs to support the CAP (EU Common Agricultural Policy) are given in Table 4.

Table 4: Direct support to farmers and rural areas according to the decision of the EU CAP in the context of the COVID-19 pandemic

\begin{tabular}{|l|l|}
\hline \multicolumn{1}{|c|}{ Volumes } & \multicolumn{1}{c|}{ Areas of support } \\
\hline $\begin{array}{l}€ 200.000 \\
\text { loans or guarantees for } \\
\text { operating costs }\end{array}$ & $\begin{array}{l}\text { Flexibility in the use of financial instruments in rural development. Farmers and } \\
\text { other rural development beneficiaries will be able to take advantage of loans or } \\
\text { guarantees to cover operating costs of up to } € 200.000 \text { on favourable terms, such as } \\
\text { low interest rates or favourable payment schedules }\end{array}$ \\
\hline $\begin{array}{l}70 \% \text { and 85\% } \\
\text { advances for CAP } \\
\text { payments }\end{array}$ & $\begin{array}{l}\text { Higher payment advances. To increase farmers' cash flows, the Commission will } \\
\text { increase advances on direct payments (from 50\% to 70\%) and some rural } \\
\text { development payments (from 75\% to 85\%). Farmers will start receiving these } \\
\text { advances from mid-October }\end{array}$ \\
\hline $\begin{array}{l}\text { Up to 120.000 euros } \\
\text { for state aid }\end{array}$ & $\begin{array}{l}\text { Possible higher state aid for farmers and food businesses under the Commission's } \\
\text { time frame for state aid, farmers can now receive a maximum aid of } € \text { 100.000 per } \\
\text { farm. Food and marketing companies can receive a maximum of } € \text { 800.000. This } \\
\text { amount can be replenished with the help of de minimis. This type of national } \\
\text { support, specific to the agricultural sector, may be granted without the prior } \\
\text { approval of the Commission and has a maximum amount of 20.000 (and } € 25.000 \\
\text { in some cases). Thanks to the new rules, EU countries can now help farmers with } \\
\text { state aid of up to } € 120.000 \text { (or } € 125.000)\end{array}$ \\
\hline Source: Coronavirus: Commission announces exceptional measures to support the agri-food sector (2020);
\end{tabular}

Supporting the agriculture and food sectors amid Coronavirus (2020)

EU countries and farmers face practical difficulties in meeting certain requirements under the CAP, and the Commission seeks to assist through a number of specific measures: extension of the deadline for submitting applications for state aid (extended until 15.06.2020); fewer farm inspections; postponement of annual reports. As part of the development of rural areas of the CAP, similar measures were taken, included in the investment initiative to respond to the coronavirus.

President Trump has instructed the US Department of Agriculture to develop a \$ 19 billion CFAP emergency assistance program to provide critical support to our farmers and ranchers, to maintain the integrity of our food supply chain. The US Department of Agriculture plans to allocate an additional \$ 873.3 million to purchase various types of agricultural products from food banks. The use of these funds will be determined by industry demand, USDA 
DOI: 10.14807/ijmp.v11i9.1418

agricultural market analysis and needs (Coronavirus: Commission announces exceptional measures to support the agri-food sector, 2020).

Following in the footsteps of the EU, the Government has adopted a package of tax benefits for businesses in the law No. 3220 "Law on Amendments to the Tax Code of Ukraine and Other Laws of Ukraine on Support of Taxpayers for the Period of Measures to Prevent the Occurrence and Spread of Coronavirus Disease (COVID-19)" (2020). In particular, a number of amendments were made to the Tax Code of Ukraine and other laws: the amount of income for single tax payers was increased; medicines and medical devices for combating coronavirus are exempt from VAT; tenants are temporarily exempt from land fees and real estate tax; the business is exempt from certain penalties; a moratorium on certain types of inspections has been introduced, etc.

Filling the budgets for cities of regional significance and large, in terms of land tax (tax holidays pay from March 1 to April 30, 2020) is not critical, and for rural areas it is almost the only stable source of income. Village budgets have been hit - they will not receive UAH 4 billion in two months, which must be compensated by other funds. That is, it should be borne in mind that the abolition of land fees will have a negative impact on filling local budgets, and the abolition of mandatory payment of SSC - on the Pension Fund's shortfall, and forced reduction of business activity during quarantine will lead to significant budget losses.

The new version of the state budget for 2020 does not provide for a reduction in expenditures aimed at supporting the agro-industrial complex. But this is subject to IMF loans. Farmers are now in dire need of government support because spending has risen sharply as the dollar has risen.

As the budget provides for UAH 4.2 billion to support the sector in 2020, support programs should be expanded, co-financed and simplified (within the framework of access to finance for all players, not individual companies). Debts for budget support in 2019 must also be repaid.

The formation of a strategy for state support for the development of agricultural production in Ukraine requires the state to solve a set of interrelated institutional tasks, which provides for Ostapenko (2015):

- creation of normative and legal framework and legislative settlement of the main economic problems of the industry; 
- providing budget support for the development of long-term lending, introduction of advanced technical means and technologies by agricultural producers due to cheaper interest rates on loans to banks and development of financial leasing, partial compensation to producers for the purchase of complex agricultural machinery and livestock;

- tax incentives for the development of highly efficient environmentally friendly industries;

- budget financing of measures for the development of selection and seed production, protection of plants and animals, increasing the genetic potential of livestock productivity, accelerated creation of an appropriate fodder base, improving soil fertility, development of agricultural land reclamation;

- expanding the availability of information resources for agricultural producers with real innovation potential by promoting their cooperation with state academic and industry scientific and research institutes.

Thus, based on the methodology of the theory of institutionalism within the strategy of state support there is an opportunity to: 1) identify and manage the development of the agricultural sector through the mechanism of state support; 2) to develop models and mechanisms of agricultural development with an optimal combination of industries and forms of management; 3) to forecast the results of the implementation of sectoral reforms and their impact on food security; 4) to develop algorithms for the implementation of systemic reforms in the field of state support of the agricultural sector.

\section{CONCLUSIONS}

Research has confirmed that information support of public administration in terms of formation and distribution of the agricultural budget is important for the efficient use of funds.

a) Analysis of budget support programs for 2019 shows that the structure of expenditures is led by the livestock industry, which accounts for almost $60 \%$ of the agricultural budget, and significant funds are allocated for financial support of producers in terms of domestic machinery and support for farmers in various areas - $15 \%$ respectively. In the dynamics of a number of recent years, agricultural budget expenditures are growing, in particular from UAH 0.596 billion in 2016 to almost UAH 5.908 billion in the 2019 project (10 times). It was possible to structure the directions of budget allocations, 
DOI: 10.14807/ijmp.v11i9.1418

directing them mainly to support small business in strategically important areas for society. That is, the dynamics of expenditures in terms of funds is quite positive, regulated as an annual percentage of gross output of the industry, which indicates certain achievements of government support policy. Some problem is the "manual" distribution of funds, when more than half of the state support is received by one or two agricultural holdings.

b) However, if we evaluate the budget support according to the OECD methodology, it turns out that against the background of European agricultural funding, Ukraine not only does not support agriculture, but also practices implicit taxation of the industry, as the difference in domestic and external prices for agricultural products is capacious, and it is embedded in the assessment of the effectiveness of public policy. In addition, since the abolition of preferential taxation, which has played the role of indirect state support since 1998, the industry has not received much more money than is financed from the budget. That is why in this area it is necessary for Ukraine to move towards the standards of the EU SAP and to separate measures to support the agricultural sector and rural areas then the funds will be used more efficiently.

c) The current state of Ukraine's development implies that reforms are needed in order to create an investment and attractive, globally competitive country. Among the priorities are recognized the following: the introduction of market circulation of agricultural land, which by increasing economic competition will increase the efficiency and productivity of agricultural land use; further policy of deregulation of the economy, to strengthen market competition.

It is established that the State Budget-20 is at the same time the successor of a larger number of programs that operated in 2017-2019 and develops new areas. The government abandoned several well-established budget programs to support agricultural development, including horticultural support, a separate livestock development program, and a general reduction in the cost of borrowed resources, instead offering a financial support program for farmers in the draft budget. The most significant program of financial support of agricultural producers in the amount of UAH 4 billion has not been disclosed in terms of support.

If we consider the agricultural support programs of the relevant ministry, the State Budget-20 provides UAH 4.5 billion, which is $23.7 \%$ less than in 2019, but $9.8 \%$ more than in 2018. Taking into account the already confirmed efficiency of the minimum amount of funding 
DOI: 10.14807/ijmp.v11i9.1418

of at least $1 \%$ of GDP, the funds should be twice as much, up to UAH 8.4 billion. And taking into account all agricultural development programs, including other ministries and financing of services for the sector, the level of support can be estimated at UAH 9.5 billion, which meets the stated criteria for the share of budget expenditures in the agricultural sector.

d) 4. In addition, it is planned to create tools to launch a full-fledged land market from 2020 that will allow small and medium-sized agricultural producers to obtain cheap credit resources for the purchase of agricultural land. Thus, UAH 4 billion has been set aside in the budget for financial support of agricultural producers, and UAH 240 million for the formation of the authorized capital of the Partial Credit Guarantee Fund.

e) Maintaining the balance of the Ukrainian agricultural sector during the systemic crisis will occur when: producers will receive support through access to finance, including cheap loans; will be able to actually benefit from a deferral or moratorium on certain types of taxes during quarantine; will receive equal conditions for all entrepreneurs (both small and large) in terms of state support. A three-month tax holidays in the form of exemption from paying the single tax of the fourth group, as well as support in terms of reducing the SSC for the quarantine period would help farmers.

f) From foreign experience, Ukraine can follow the principles of state support for the most vulnerable areas of the agricultural economy, as well as support for small business and rural development.

g) In many state support measures, the achievements are formed in the areas of budget support, close to WTO requirements, the challenges are insufficient funding, illconceived mechanisms for implementing certain programs, support for those forms of management that do not need it most, controllability of the allocation of funds and producers' distrust of government programs.

\section{REFERENCES}

ACCOUNTING CHAMBER OF UKRAINE (2018) On the results of the audit of the effectiveness of the exercise of powers by public authorities in terms of completeness and timeliness of payment of taxes by economic entities in agriculture: report. Available: http://www.ac-rada.gov.ua/doccatalog/document/16758046/Zvit_27-4_2018.pdf. Access: 15/03/2020. (in Ukrainian).

AGRARIAN COMMITTEE OF THE VERKHOVNA RADA (2020) Available: https:/itd.rada.gov.ua/radatransl/Home/Committees/en. Access: 15 May 2020. (in Ukrainian).

BORODINA, O. M.; KYRYZYUK, S. V. (2008) Institutional principles of changes in state 
INDEPENDENT JOURNAL OF MANAGEMENT \& PRODUCTION (IJM\&P)

http://www.ijmp.jor.br

v. 11, n. 9, Special Edition (Baltic States), November 2020

ISSN: 2236-269X

DOI: 10.14807/ijmp.v11i9.1418

support of the agricultural sector in accordance with WTO requirements. Economics and Forecasting, v. 3, p. 87-106. (in Ukrainian).

CABINET OF MINISTERS OF UKRAINE (2018) Project "Accelerating investment in agriculture in Ukraine". Available: https://www.kmu.gov.ua/ua/news/minagropolitiki-tasvitovij-bank-obgovorili-proekt-priskorennya-investicij-u-silske-gospodarstvo-ukrayini. Access: 15 May 2020. (in Ukrainian).

CĂLIN, H. C.; IZVORANU, A. M.; TODIRICA, I. C. (2020) The Impact of Globalization on Farmers Income. Evidence from Poland and Romanian Agriculture. The CAP and National Priorities within the EU Budget after. Available: https://ierigz.waw.pl/download/22043-Calin_Izvoranu_Todirica.pdf. Access: 20 May 2020.

CORONAVIRUS (2020) Commission announces exceptional measures to support the agri-food sector Available at: https://ec.europa.eu/commission/presscorner/ detail/en/IP_20_722. Access: 15/05/2020.

DEMYANENKO, M. Ya. et al. (2011) State policy of financial support for the development of the agricultural sector of agriculture: monograph. Kyiv, NSC IAE UAAS. (in Ukrainian).

EUROPEAN PLAN FOR UKRAINE (2017) Available: https://g8fip1kplyr33r3krz5b97d1wpengine.netdna-ssl.com/wp-content/uploads/2017/11/Presentation-EuropeanPlan Ukraineupdate.pdf. Access: 11 May 2020.

FEED EVERYONE AND NOT DIE OF HUNGER OURSELVES (2020) Available: https://zn.ua/ariculture/nakormit-vseh-i-samim-s-goloda-ne-umeret-352057_.html. Access: 10 May 2020. (in Ukrainian).

GALUSHKO, V. P.; DIBROVA, A. D.; DIBROVA, L. V. (2006) Methodological and practical aspects of assessing the level of state support for agricultural producers in Ukraine. Ekonomika APK, v. 3, p.3-15. (in Ukrainian).

HEINEMANN, F.; WEISS, S. (2018) The EU budget and Common Agricultural Policy beyond 2020: Seven more years of money for nothing? EconPol Working Paper, v. 17. Available: https://www.ifo.de/publikationen/2018/working-paper/eu-budget-and-commonagricultural- policy -beyond-2020-seven-more. Access: 25 May 2020.

INFORMATION AND ANALYTICAL PORTAL OF THE AIC OF UKRAINE. Available: https://agro.me.gov.ua/en. Access: 15 May 2020. (in Ukrainian).

LAIKO, P. A. (1998) State financial support of agriculture in a market economy. Kyiv: NSC IAE UAAS. (in Ukrainian).

LAW OF UKRAINE (2007) On the Basic Principles of Information Society Development in Ukraine for 2007-2015. Available at: https://zakon.rada.gov.ua/laws/show/537-16\#Text. Access: 16 May 2020. (in Ukrainian).

LAW OF UKRAINE (2020) About the State Budget of Ukraine for 2020 (Information of the Verkhovna Rada (VVR), 2020, 5, p.31). Available:

https://zakon.rada.gov.ua/laws/show/294-20?lang=en\#Text/. Access: 15 May 2020. (in Ukrainian).

LINYOV, K. O. (2016) Information support of public administration and civil service Textbook, SFSU, Kyiv. (in Ukrainian).

LUPENKO, YU. O.; MESEL-VESELIAK, V. I. (2012) Strategic directions of development of agriculture of Ukraine for the period till 2020. Kyiv: National Research 
INDEPENDENT JOURNAL OF MANAGEMENT \& PRODUCTION (IJM\&P)

http://www.ijmp.jor.br

v. 11, n. 9, Special Edition (Baltic States), November 2020

ISSN: 2236-269X

DOI: 10.14807/ijmp.v11i9.1418

Centre "Institute of Agrarian Economics". (in Ukrainian).

MATTHEWS, A. (2016) The dependence of EU farm income on public support.

Available: http://capreform. eu/the-dependence-of-eu-farm-income-on-public-support.

Access: 24 June 2020.

MILOJEVIĆ, I.; ĆURČIĆ, M. (2017) Role of the Budget in Financing of Agriculture. Institute of Agriculture Economics: Sustainable agriculture and rural development in terms of tge Republic of Serbia strategic goals realization within the Danube region, p. 360-373. Available: https://www.cabdirect.org/cabdirect/abstract/20173281659. Access: 21 May 2020.

MINISTRY FOR DEVELOPMENT OF ECONOMY, TRADE AND AGRICULTURE OF UKRAINE (2020) Available: https://me.gov.ua/?lang=en-GB. Access: 19 May 2020. (in Ukrainian).

MINISTRY OF AGRARIAN POLICY AND FOOD OF UKRAINE (2019) Available: minagro.gov.ua/. Access: 21 June 2020. (in Ukrainian).

MOLDAVAN, L. V. (2016) The role of cooperatives in ensuring the competitiveness of small and medium agribusiness: theoretical and practical aspects. Theoretical and applied issues of economics, v. 1, p. 23-31. (in Ukrainian).

OLIYNYK, O. V.; KALASHNIKOVA, T. V.; KLEPCHEVA, O. V. (2014) State support in ensuring the economic stability of agricultural enterprises. Ekonomika APK, v. 2, p. 51-56. (in Ukrainian).

OSTAPENKO, T. V. (2015) Priorities of state regulation of domestic agro-industrial complex in the context of strategy of economic modernization. Problems and prospects of economy and management, v. 1, p. 98-103. (in Ukrainian).

PROKOPA, I.; BORODINA, O. (2016) Support of family farming: slogans and actions. Available at: https://zn.ua/ukr/ariculture/pidtrimka-simeynogo-fermerstva-gasla-i-diyi_.html. Access: 08 June 2020. (in Ukrainian).

RADCHENKO, O. D. (2017) Economic and social consequences of changing the mechanism of budget support of the agrarian sector of Ukraine. Zbirnyk naukovykh prats

Universytetu derzhavnoi fiskalnoi sluzhby Ukrainy, v.1, p. 241-255. (in Ukrainian).

RADCHENKO, O. D. (2019) Financial potential of sustainable development of the agrarian sector. Ekonomika APK, v. 1, p. 27-38. (in Ukrainian).

RADCHENKO, O. D.; MELNICHUK, O. O. (2019) Achievements and challenges of state support of the agricultural sector of Ukraine in the context of European integration. Market Infrastructure, v. 31, p. 168-173. Avaible: http://www.market-infr.od.ua/uk/31-2019. Access: 10 June 2020. (in Ukrainian).

RADCHENKO, O.; LAZUTINA, L. (2017) State financial support of rural development of Ukraine in the light of European integration processes. Financial support of the agrarian sector: domestic and foreign experience: monogr; for order. Davydenko NM Kyiv: NUBIP of Ukraine, p. 54-69. (in Ukrainian).

RADCHENKO, O.; SEMENYSHENA, N.; SADOVSKA, I.; NAHIRSKA, K.; POKOTYLSKA, N. (2020) Foresight Development Strategy of the Financial Capacity: Comparative Study of the Ukrainian Agricultural Sector. Engineering Economics, v. 31, p. 178-187. DOI: 10.5755 / j01.ee.31.2.24340.

SAVITSKA, S.; ZAIKA, S.; SVYSTUN, L.; KOVAL, L.; HAIBURA, Y. (2020) Investment 
DOI: 10.14807/ijmp.v11i9.1418

providing sustainable development of rural areas in Ukraine. Independent Journal of Management \& Production, v. 11, n. 8, p. 571-586. DOI:

dx.doi.org/10.14807/ijmp.v11i8.1218.

SCOWN, M. W.; BRADY, M. V.; NICHOLAS, K. A. (2020) Billions in misspent EU agricultural subsidies could support the Sustainable Development Goals. One Earth, v. 3, n. 2, p. 237-250. Available: https://www.cell.com/one-earth/pdf/S2590-3322(20)30355-9.pdf. Access: 11 June 2020.

SEMENYSHENA, N. V.; RADCHENKO, O. D. (2011) Institutions of the sphere of Accounting of Budgetary Financing of Agriculture. Scientific periodicals of KNEU Formation of market economy. Special issue. (2011 - 75). Kyiv: SHEI "Kyiv National Economic University named after V. Hetman", p. 477-485. (in Ukrainian).

SOLOVYOV, S. G. et al. (2015) Information component of state policy and management: monograph. In: Gritsyak NV (Ed.); Nat. acad. state упр. under the President of Ukraine, Department of Inform. policy and electron. government. Kyiv: KIS. (in Ukrainian).

SUPPORTING THE AGRICULTURE AND FOOD SECTORS AMID CORONAVIRUS (2020) Available: https://ec.europa.eu/info/food-farming-fisheries/farming/coronavirusresponse_en. Access: 18 July 2020.

THE WORLD BANK. (2020) Available: https://www.worldbank.org/. Access: 19 June 2020.

TULUSH, L. D.; RADCHENKO, O. D. (2020) State support for farms and farms to overcome the effects of the COVID-19 pandemic. In: COUNTERACTING THE MINIMIZATION OF TAX PAYMENTS: WORLD EXPERIENCE AND PRACTICE OF UKRAINE: a collection of materials of the III Scientific and Practical Round Table (Irpin, May 15, 2020). Irpin: Research Institute of Fiscal Policy, p. 209-213. (in Ukrainian).

VDOVENKO, N. M.; NAKONECHNA, K. V.; PAVLENKO, M. M. (2017) Methodical component of the performance of state support producers mechanism. Naukovyi visnyk Polissia, v. 4. n. 12, part 1, p. 22-27. DOI: 10.25140/2410-9576-2017-1-4(12)-22-27.

VDOVENKO, N. M.; NAKONECHNA, K. V.; SAMSONOVA, V. V. (2017) Mechanisms and tools of supply regulation in agricultural sector of economy. Naukovyi visnyk Polissia, v. 3, n 11, part 1, p. 165-169. DOI: 10.25140/2410-9576-2017-1-3(11)-165-169.

ZAWISZA, S.; PRUS, P.; BEBEN, S. (2019) Development of agricultural farms in terms of Common Agricultural Policy support in the opinion of farmers. Economic science for rural development, v. 50, p. 264-271. DOI: 10.22616/ESRD.2019.033.

ZHALILO, YA. A. (2009) Theory and practice of formation of effective economic strategy of the state: monograph. Kyiv: NISS. (in Ukrainian). 